\title{
E-Government of Village Empowerment
}

\author{
Ayu Tri Andira, Phong Thanh Nguyen, S. Rema Devi, K. Shankar, Satria Abadi, Wahidah Hashim, \\ Andino Maseleno
}

\begin{abstract}
South Pringsewu is the name of a village located in Pringsewu district. This village has the main potential, namely agriculture and industry. To develop its potential it needs to be updated from the system that has been used in empowering the potential of the village manually and not yet using the information system even in the form of a website. The purpose of this research was to select South Pringsewu Village that has the potential of villages that need to be empowered using information technology. Information Technology is needed to facilitate the access, management and empowerment of village potentials, so that it is expected to be able to improve the progress and quality of South Pringsewu Village. The author conducted the research by observation, interview, and literature study methods and built web-based applications through the stages of planning, system analysis, system design and design, and system implementation using the PHP programming language.
\end{abstract}

Keywords : E-Government, Village Empowerment, Application.

\section{INTRODUCTION}

\section{A. Background}

Information and communication technology in the globalization era is developing rapidly [1]. The rapid development of information and communication technology will open up opportunities to create, to access to process and to utilize information precisely and accurately [2]. Information is a valuable commodity to be mastered in order to continuously improve the progress and quality of the village of South Pringsewu Village [3]. Along with the progress of information and communication technology at this time in the village of South Pringsewu

Revised Manuscript Received on July 22, 2019.

* Correspondence Author

Ayu Tri Andira, Department of Information Systems, STMIK Pringsewu, Lampung, Indonesia.

Phong Thanh Nguyen*, Department of Project Management, Ho Chi Minh City Open University, Vietnam. E-mail: phong.nt@ou.edu.vn

S. Rema Devi, Associate Professor \& Head Department of English, Kalasalingam Academy of Research and Education, Krishnankoil, India.

E-mail: remadevi.s@klu.ac.in

K. Shankar, Department of Computer Applications, Alagappa University, India. E-mail: shankarcrypto@gmail.com

Satria Abadi, Department of Information Systems, STMIK Prin gsewu, Lampung, Indonesia.

Wahidah Hashim, Institute of Informatics and Computing Energy, Universiti Tenaga Nasional, Malaysia.

Andino Maseleno, Institute of Informatics and Computing Energy, Universiti Tenaga Nasional, Malaysia.
Village, there has not been a system that uses technology e- government or village-based information system [4]. The web is needed as a medium to provide information on village potential of South Pringsewu Village with wider coverage and can provide efficient and effective services in order to attract interested investors to cooperate in village empowerment and village potential [5]. Realizing the magnitude of the benefits of information technology, the authors took the initiative to build web-based applications as a solution to overcome obstacles in accessing information on the South Pringsewu Village [6]. E-Government by using the web offers public services that can be accessed in 24 hours [7]. Viewing the phenomena that occur at this time convinced the author to build an information system with Web-based e-government [8]. The web-based E-Government system provides information access services in the village of South Pringsewu to be easier, faster, and more accurate [9]. It is expected that the new system can improve the progress and quality of the village of South Pringsewu Village [10].

\section{B. Problem Formulation}

By looking at the background above and seeing the phenomena occured, then the problem formulation of South Pringsewu Village can be drawn, namely:

1. The need of web-based information system that is able to convey information about South Pringsewu Village and its potential contained in the village.

2. Required information system in the of government in the South Pringsewu village.

3. Empowerment of villages and the potential of South Pringsewu Sub-Distrcit in the efforts to improve village progress and quality.

4. Facilities and infrastructure regarding and supporting facilities for the web-based online E-Government system so that the delivery of information in South Pringsewu Village is faster and more accurate.

\section{Objectives}

According to the formulation of the needs, the objectives were:

1. To generate an information system that can be used as a means of delivering government information and empowering the potential of South Pringsewu Village in the website. 
2. To Optimize the use of information technology that has been built to process government data and the potential of South Pringsewu Village to produce information that can be accessed accurately.

\section{Benefit}

The results of this study have several benefits namely :

1. Practical benefits: it is expected that the results of this study can be used as a reference in providing directions for determining policies and decisions appropriately, especially in South Pringsewu village.

2. Theoretical benefits: the results of this policy are expected to provide benefits in the development of web-based information systems theoretical studies.

3. Policy benefits: it is expected that the results of this study can be used as a solution to replace systems that have been running manually into web-based information systems.

4. Improving community life and progress of the South Pringsewu Village, especially in developing the village's potential to be more publicly known.

\section{LITERATURE REVIEW}

\section{A. Definition of E-government}

Generally, it can be said that e-government or abbreviated as e-gov is a computer and internet-based application that is used to improve government relations and services to citizens or is referred to as G2C (Government to Citizen) [11]. In addition, the relationship between the government and companies is often referred to as G2B (Government to Government) as its partners [12]. The development of more communicative relationships, ease of administrative services and transactions as well as the presentation of information is the basis for the e-gov application development [13]. E-government is defined as a new mechanism of interaction between the government and the community and other parties concerned, where the use of communication technology with the aim of improving public services quality [14].

\section{B. Definition of Website}

Website or site can also be interpreted as a collection of pages that display text data information [15], static or motion figure data, animated data [16], sound, video or a combination of static and dynamic that forms a series of interrelated buildings that connect each others (hyperlink) [17]. Website is a collection of web pages placed in one place or a site. So on a website there are web pages [18].

\section{Definition of Database}

Data collection (elementary) that is logically related in presenting phenomena / facts structured in certain domains to support applications in certain systems [19]. Database is a collection of data, generally describing the activities of one or more related organizations [20].

\section{MSQL}

MSQL is fast, easy to use and as a relational database management system (RDBMS) that is used for databases on several websites [21].

\section{E. PHP}

PHP is a language (scripting language) specifically designed for the use of the web. PHP is a tool for creating dynamic web pages [22]. The rich of feature in creating web design and programming will be easier [23]. PHP is short for Hyper Text Processor. At the beginning of its development by the Laddrof Formula, he called it the Personal Home Page tool [24].

\section{F. HTML}

HTML is Hyper Text Markup Language. HTML is the language used to create a website or HomePage. Every document on the web is written in HTML format. All clicks, figures, multimedia documents, forms that can be filled and so on are based on HTML.

\section{RESEARCH METHODOLOGY}

\section{A. Data Collection Method}

Data collection method can be done by :

\section{Literature Method [25]}

Literature Method is a data collection technique by studying references in the form of documents or files and collecting data, laws and regulations, books, and research journals through literature study [26]. The need for data that reveals the indicators used by potential investors for investment decision making is obtained through a literature study of books and research journals [27]. Literature study is also conducted to find out and apply information technology capabilities that will be applied in the system [28].

\section{Observation [29]}

Observation is a technique or approach to get primary data by observing the data object directly [30].

\section{Documentation [31]}

Through this method, the author perpetuates through Figure, gathering documents, archives and existing data as research material [32].

\section{Interview [33]}

Interview is a way or technique to get information or data from interview or respondent by direct interview (face to face), between interviewer and interview [34].

\section{B. System Development Method}

Development of the system means compiling a new system to replace the old system as a whole or improve existing systems [35]. 
The main stages of system development consist of structured development methods [36] with a system development life cycle approach (System Development Life Cycle or SDLC) as shown in figure 1 . It consists of several stages including:

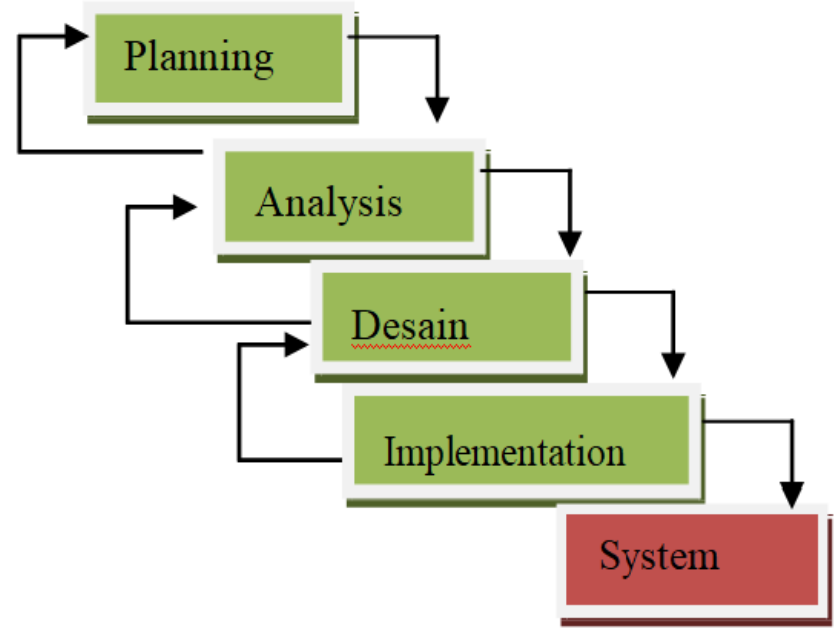

Figure 1. System Development Life Cycle

\section{Planning [37]}

At this stage, it is more focused on understanding the needs and problems by defining the goals and objectives of the system to be built [38].

2.System Analysis [39]

In this stage, an analysis of the existing system is carried out by a method, namely interviews with relevant parties and observing the condition of the village area that will be the object of research [40]. That must done in this stage is: determining objects, studying the organization, analyzing input and output needs and evaluating the use of the system. 3. System Design [41]

In the system design stage adapted to the needs and problems encountered in the research object [42]. At this stage performed some activities namely : database design, user interface design, hardware requirements, software and network requirements [43].

4. System Implementation [44]

In the implementation phase there are several tasks that must be carried out including implementing the design in some components - then refining the architecture and subsequently implementing it by making programs and testing programs [45].

5. Operation and System maintenance

At this stage the user is trained and evaluated of the running system carried out, if there are deficiencies or errors it must be held the repair and maintenance [46].

\section{IMPLEMENTATION}

\subsection{Homepage}

Figure 2 shows Homepage implementation .

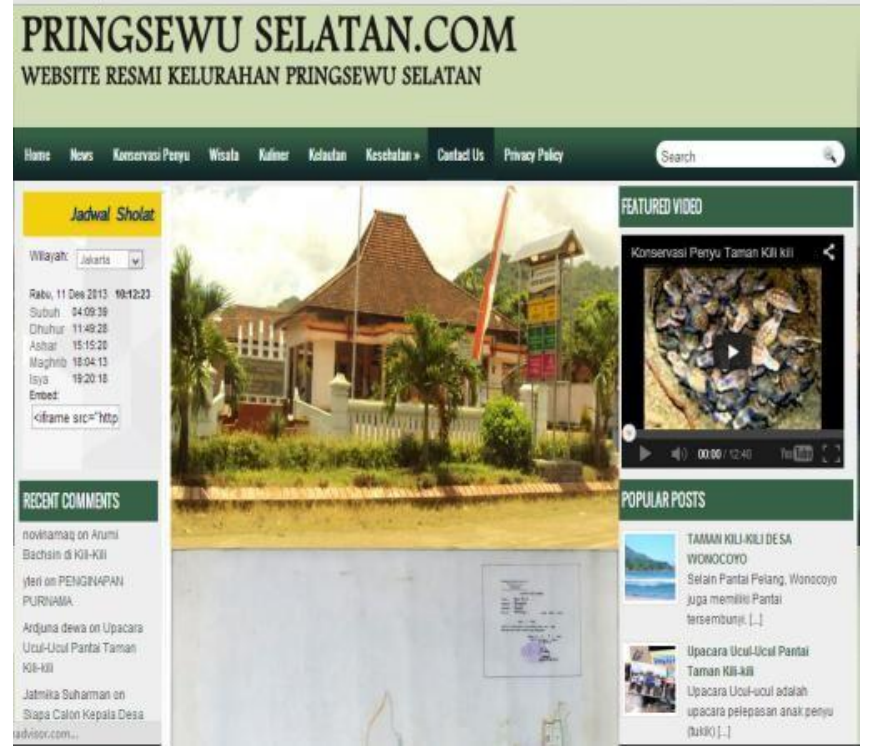

Figure 2: Homepage Implementation

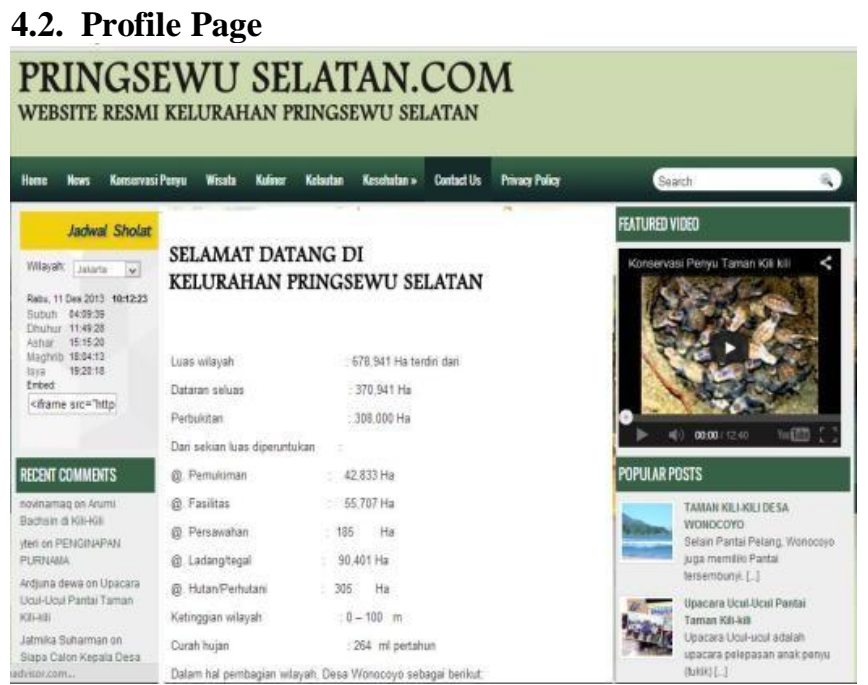

Figure 3: Profile Page

\subsection{Vision and Mission Page}

\section{PRINGSEWU SELATAN.COM WEBSITE RESMI KELURAHAN PRINGSEWU SELATAN}

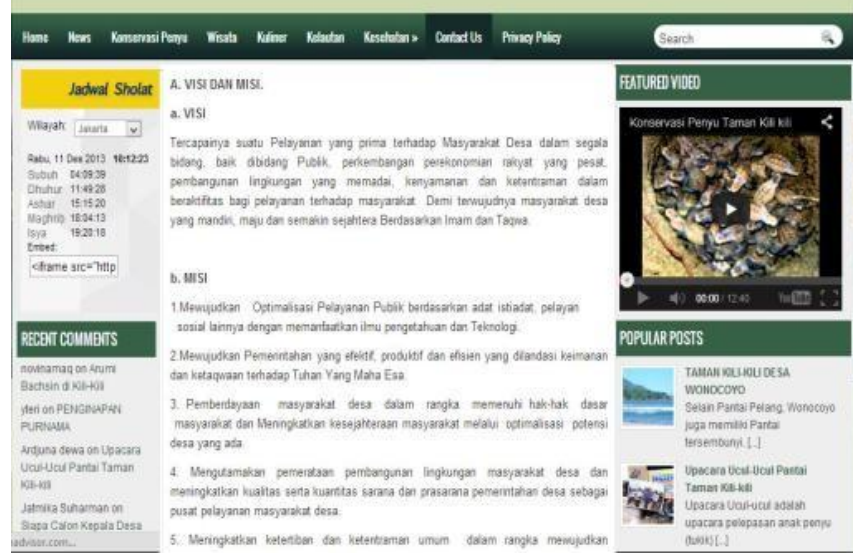

Figure 4: Vision and Mission Page

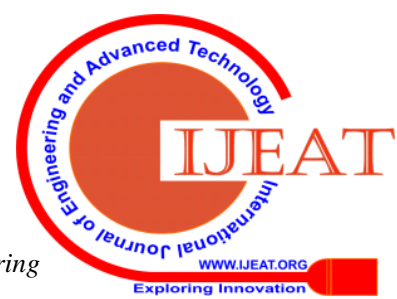




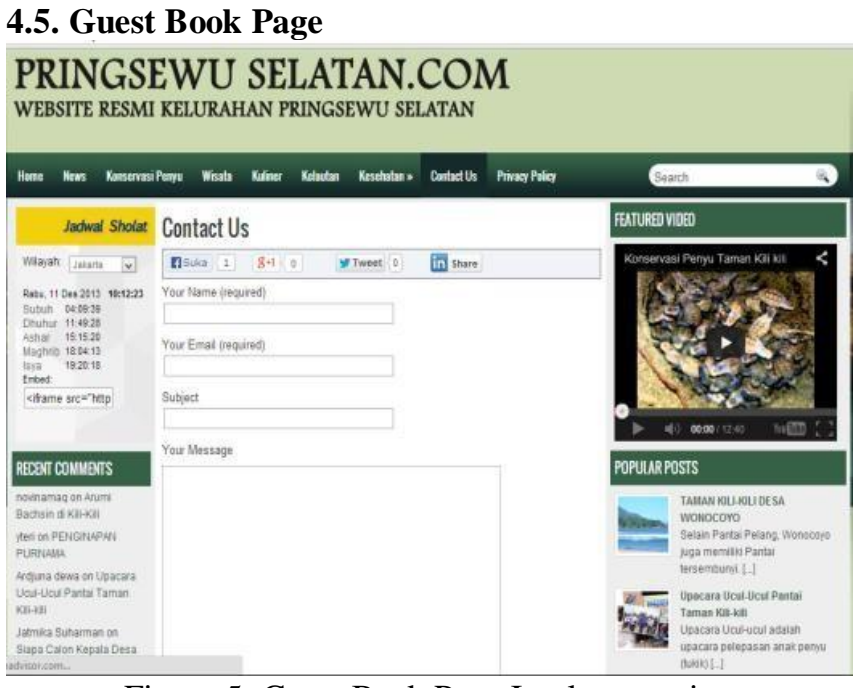

Figure 5: Guest Book Page Implementation

\section{CONCLUSION}

Village empowerment and village potential are very important in improving the goal is to advance and introduce the village to the public. The development of an information system using a website is the solution to access information and introduce South Pringsewu Village to the public. For the community, especially South Pringsewu Village, to be able to empower village and increase the potential of the village well in order to achieve a better standard of living with a web-based information system. If there are deficiencies and errors in writing this journal, the authors expect constructive criticism and suggestions for further improvement..

\section{REFERENCES}

1. Chienwattanasook, K., Wattanapongphasuk, W., Prianto, A., \& Jermsittiparsert, K. 2019. "Corporate Entrepreneurship and Business Performance of Logistic Companies in Indonesia.” Industrial Engineering \& Management Systems 18 (3): 538-547.

2. Dawabsheh, M., Hussein, A., \& Jermsittiparsert, K. 2019. "The Triangular Relationship between TQM, Organizational Excellence and Organizational Performance: A Case of Arab American University Palestine." Management Science Letters 9 (6): 921-932.

3. Jermsittiparsert, K., Siam, M., Issa, M., Ahmed, U., \& Pahi, M. 2019. "Do Consumers Expect Companies to Be Socially Responsible? The Impact of Corporate Social Responsibility on Buying Behavior." Uncertain Supply Chain Management 7 (4): 741-752.

4. Syazali, M., Putra, F., Rinaldi, A., Utami, L., Widayanti, Umam, R., \& Jermsittiparsert, K. 2019. "Partial Correlation Analysis Using Multiple Linear Regression: Impact on Business Environment of Digital Marketing Interest in the Era of Industrial Revolution 4.0." Management Science Letters 9 (11): 1875-1886.

5. Sae-Lim, P. \& Jermsittiparsert, K. 2019. "Is the Fourth Industrial Revolution a Panacea? Risks toward the Fourth Industrial Revolution: Evidence in the Thai Economy." International Journal of Innovation, Creativity and Change 5 (2): 732-752.

6. Chatchawanchanchanakij, P., Arpornpisal, C., \& Jermsittiparsert, K. 2019. "The Role of Corporate Governance in Creating a Capable Supply Chain: A Case of Indonesian Tin Industry." International Journal of Supply Chain Management 8 (3): 854-864.

7. Hartinah, S., Suharso, P., Umam, R., Syazali, M., Lestari, B., Roslina, R., \& Jermsittiparsert, K. 2020. “Teacher's Performance Management: The Role of Principal's Leadership, Work Environment and Motivation in Tegal City, Indonesia.” Management Science Letters 10 (1): 235-246.

8. Haseeb, M., Hussain, H., Slusarczyk, B., \& Jermsittiparsert, K. 2019. "Industry 4.0: A Solution towards Technology Challenges of Sustainable Business Performance." Social Sciences 8 (5): 184.

9. Haseeb, M., Hussain, H., Kot, S., Androniceanu, A., \& Jermsittiparsert, K. 2019. "Role of Social and Technological Challenges in Achieving a Sustainable Competitive Advantage and Sustainable Business Performance." Sustainability 11 (14): 3811.
10. Haseeb, M., Kot, S., Hussain, H., \& Jermsittiparsert, K. 2019. "Impact of Economic Growth, Environmental Pollution, and Energy Consumption on Health Expenditure and R and D Expenditure of ASEAN Countries." Energies 12 (19): 3598

11. Huda, S., Tsani, I., Syazali, M., Umam, R., \& Jermsittiparsert, K. 2020 "The Management of Educational System Using Three Law Auguste Comte: A Case of Islamic Schools.” Management Science Letters 10 (3) (In press), DOI: 10.5267/j.msl.2019.9.018.

12. Usak, M., Kubiatko, M., Shabbir, M., Dudnik, O., Jermsittiparsert, K., \& Rajabion, L. 2019. "Health Care Service Delivery Based on the Internet of Things: A Systematic and Comprehensive Study." International Journal of Communication Systems 32 (14): e4179.

13. Jermsittiparsert, K., Ambarita, D., Mihardjo, L., \& Ghani, E. 2019 "Risk-Return through Financial Ratios as Determinants of Stock Price: A Study from ASEAN Region." Journal of Security and Sustainability Issues 9 (1): 199-210.

14. Thabhiranrak, T. \& Jermsittiparsert, K. 2019. "Towards Sustainable Functioning of Organization: Women Empowernment and Corporate Management Culture.” Journal of Security and Sustainability Issues 9 (1): 321-332.

15. Chienwattanasook, K. \& Jermsittiparsert, K. 2019. "Impact of Entrepreneur Education on Entrepreneurial Self-Employment: A Case Study from Thailand." Polish Journal of Management Studies 19 (1): 106-116.

16. Jermsittiparsert, K., Sutduean, J., Sriyakul, T., \& Khumboon, R. 2019. "The Role of Customer Responsiveness in Improving the External Performance of an Agile Supply Chain." Polish Journal of Management Studies 19 (2): 206-217.

17. Jermsittiparsert, K., Sutduean, J., \& Sriyakul, T. 2019. "Effect of Service Innovation and Market Intelligence on Supply Chain Performance in Indonesian Fishing Industry." Industrial Engineering \& Management Systems 18 (3): 408-417.

18. Jermsittiparsert, K., Namdej, P., \& Somjai, S. 2019. "Green Supply Chain Practices and Sustainable Performance: Moderating Role of Total Quality Management Practices in Electronic Industry of Thailand." International Journal of Supply Chain Management 8 (3): 33-46.

19. Somjai, S. \& Jermsittiparsert, K. 2019. "The Trade-off between Cost and Environmental Performance in the Presence of Sustainable Supply Chain." International Journal of Supply Chain Management 8 (4): 237-247.

20. Jermsittiparsert, K. \& Sawasdee, A. 2012. "Formal Education for Non-Thai or Undocumented Person in Thailand amidst the Challenge of Nationalism and Transnationalism: A Case Study of Wat Sirimongkhol School, Samut Sakhon Province." Kasetsart Journal - Social Sciences 33 (2): 203-213.

21. Ambika, P., Ayshwarya, B, Livshits, Y.A., Nguyen, P.T., Hashim, W., Shankar, K., Maseleno, A., Self-education as a condition of professional and personal development of a future specialist, Religación. Revista de Ciencias Sociales y Humanidades, Vol. 4, No. 16, 2019. pp. 499-205.

22. Suhartono, Nguyen, P.T., K. Shankar, K., Hashim, W., Maseleno, A., Brain Tumor Segmentation and Classification using KNN Algorithm, International Journal of Engineering and Advanced Technology, Vol. 8, Issue 6S, 2019. pp.706-711.

23. Muruganantham A., Nguyen, P.T., Lydia, E.L., Shankar, K., Hashim, W., Andino Maseleno, Big Data Analytics and Intelligence: A Perspective for Health Care, International Journal of Engineering and Advanced Technology, Vol. 8, Issue 6S, 2019. pp.861-864.

24. Asih, E.S., Kasmi, Nguyen, P.T., Lydia, E.L., Shankar, K., Hashim, W., Andino Maseleno, A., Mobile E-Commerce Website for Technology-Based Buying Selling Services, International Journal of Engineering and Advanced Technology, Vol. 8, Issue 6S, 2019. pp.884-888.

25. Kumar, R., Ayshwarya, B., Konovalova, E.Y., Nguyen, P.T., Hashim, W., Shankar, K., Maseleno, A., Approaches and technologies for the formation of future specialists' motivation, Religación. Revista de Ciencias Sociales y Humanidades, Vol. 4, No. 16, 2019. pp. 492-498. 
26. Rusliyadi, M., Kumalasari, R.T., Nguyen, P.T., Hashim, W., Maseleno, A., Potential Jatropha Curcas (Jatropha Curcas L.) Germplasm by Exploration In Gorontalo Province Indonesia, International Journal of Recent Technology and Engineering (IJRTE), Vol. 8, Issue 2S3, 2019. pp.1617-1624.

27. Ambika P., Ayshwarya, B., Nguyen, P.T., Hashim, W., Rinjani, F., Muslihudin, M., Shankar, K., Denisova, O.P., Maseleno, A., The Best of Village Head Performance: Simple Additive Weighting Method, International Journal of Recent Technology and Engineering (IJRTE), Vol. 8, Issue 2S3, 2019. pp.1568-1572.

28. Sivaram, M., Ayshwarya, B., Hashim, W., Nguyen, P.T., Shankar, K., Prabowo, E., Abadi, S., Huda, M., Ochepovsky, A.V., Maseleno, A., School Now, Pay Later, Revista San Gregorio, No. 32, Special Issue August 2019. pp. 196-203.

29. Sivaram, M., Ayshwarya, B., Pribadi, M.R., Nguyen, P.T., Shankar, K., Mohammed, A.S., Abadi, S., Huda, M., Putra, D.P., Hashim, W., Maseleno, A., Porkodi, V., Manikandan, V., Ochepovsky, A.V., Saving Private Money, Revista San Gregorio, No. 32, Special Issue August 2019. pp. 204-211.

30. Maseleno, A., Ayshwary, B., Ivanova, T.N., Hashim, W., Nguyen, P.T., Shankar, K., Kristiawan, M., Huda, M., General theoretical and philosophical aspects of modern education, Revista San Gregorio, No. 32, Special Issue August 2019. pp. 212-217. 